\title{
A case of anterior internal ophthalmomyiasis: case report
}

\section{Oftalmomiíase interna anterior:relatodecaso}

\author{
Vinicius da Silveira Saraiva ${ }^{1}$ \\ Miguel Hage Amaro ${ }^{2}$ \\ Rubens Belfort Jr. ${ }^{3}$ \\ Miguel Noel Burnier Jr. ${ }^{4}$
}

\begin{tabular}{|l|}
\hline ABSTRACT \\
\hline A case of anterior internal ophthalmomyiasis is described. A 27-year-old \\
female from Northern Brazil presenting with anterior uveitis and vitritis had \\
a fly larva surgically removed from the anterior chamber of the left eye. The \\
species was Cochliomyia hominivorax. The larva was covered by macro- \\
phages and foreign body giant cells characterizing a foreign body granu- \\
lomatous reaction.
\end{tabular}

Keywords: Myiasis; Anterior chamber; Screw worm infection; Diptera, Case reports [publication type]

\section{INTRODUCTION}

Myiasis is the infestation of any part of the body by fly larvae (genus Diptera). It most commonly occurs in areas with tropical or temperate climates $^{(1)}$.

Fly eggs may be accidentally deposited on the eyelids or conjunctiva. Once larvae hatch they penetrate and feed on tissues, sometimes gaining access to the eye. The presence of fly larvae inside the eye is termed internal ophthalmomyiasis. Internal ophthalmomyiasis is classified as anterior and posterior, based on the finding of larvae in the anterior or posterior segment of the eye, respectively ${ }^{(2)}$.

The purpose of this paper is to report a rare case of anterior internal ophthalmomyiasis with documented histopathology of the causative larva.

\section{CASE REPORT}

A 27-year-old female from Belém, Pará (Brazilian Amazon region) presented with decreased visual acuity, photophobia and pain in the left eye for 3 weeks. Best corrected visual acuity (BCVA) was 20/20 OD and hand motions OS. Right eye examination was unremarkable. Left eye showed no conjunctival hyperemia, anterior chamber cells $2+$ and flare $2+$, and intense vitritis precluding fundus examination. There was a free-floating, moving larva in the anterior chamber of the left eye (Figure 1A). No ocular perforation was noted. There were no dermatological alterations in the periocular region or elsewhere in the body. Chest X-ray, complete blood count, erythrocyte sedimentation rate and stool sample for ova and parasites were normal. The larva was surgically removed by irrigation and aspiration of the anterior chamber and sent to Montreal, Canada for histopathologic examination. The patient received a short course of topical steroid and antibiotic treatment postoperatively.

Identification was made by Dr. Douglas Wear from the Department of Infectious Diseases, Armed Forces Institute of Pathology, USA. The speci- 
men consisted of a fly larva measuring $4 \times 1$ millimeters with characteristic posterior spiracular plates (Figure 1B). Microscopically, the cuticle and hypodermis were also characteristic of fly larva (Figure 1C, D). The species was Cochliomyia hominivorax. Notably, there were pigment-laden macrophages and foreign body giant cells on the surface of the larva (Figure 1C, D).

Six weeks after surgery, BCVA was 20/30 in the left eye with no inflammatory signs and no subretinal tracking.

\section{DISCUSSION}

Internal ophthalmomyiasis is a rare disease caused by a limited number of species of Diptera flies that are capable of penetrating tissue. This group includes Cochliomyia hominivorax, which is a common causative species of myiasis in tropical areas. Frequently, but not necessarily, little inflammation is seen until the larvae $\operatorname{die}^{(2-3)}$.

The entry site into the eye is usually not apparent. In most cases the larvae are found in the posterior segment (in the vitreous cavity or subretinal space). Clinical presentations include posterior uveitis, retinal detachment and retinal pigment epithelium changes (subretinal tracking) $)^{(4)}$.

Anterior internal ophthalmomyiasis is less common than its posterior counterpart. It presents clinically as anterior uveitis. Sometimes accompanied by posterior segment inflammation, which may be severe as in the present case $\mathrm{c}^{(2,5-8)}$.

To the best of our knowledge, this is the first time the human host response to a fly larva in the anterior chamber was documented with histopathology. There were macrophages and foreign body giant cells on the surface of the larva characterizing a foreign body granulomatous reaction.
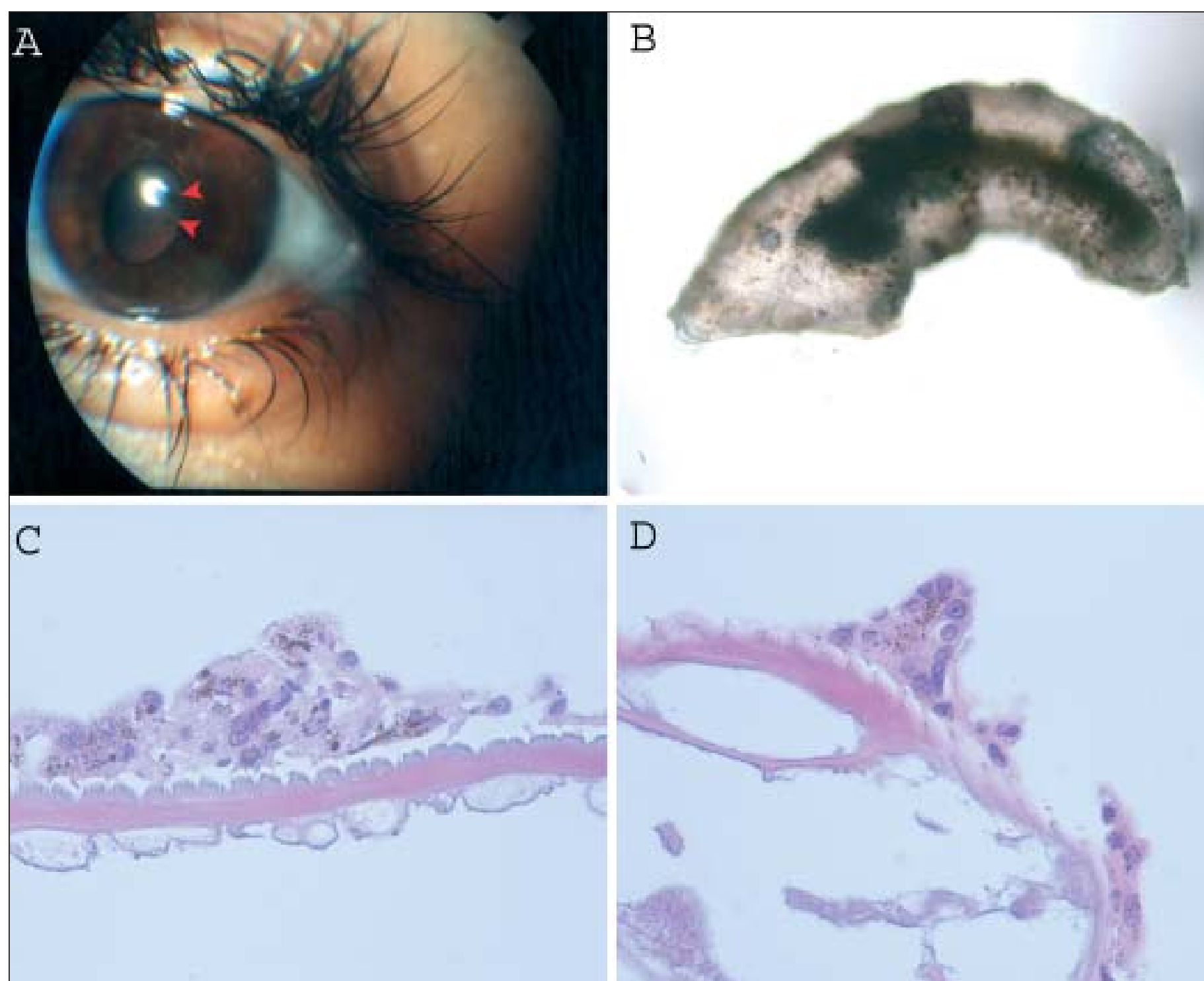

\section{D}

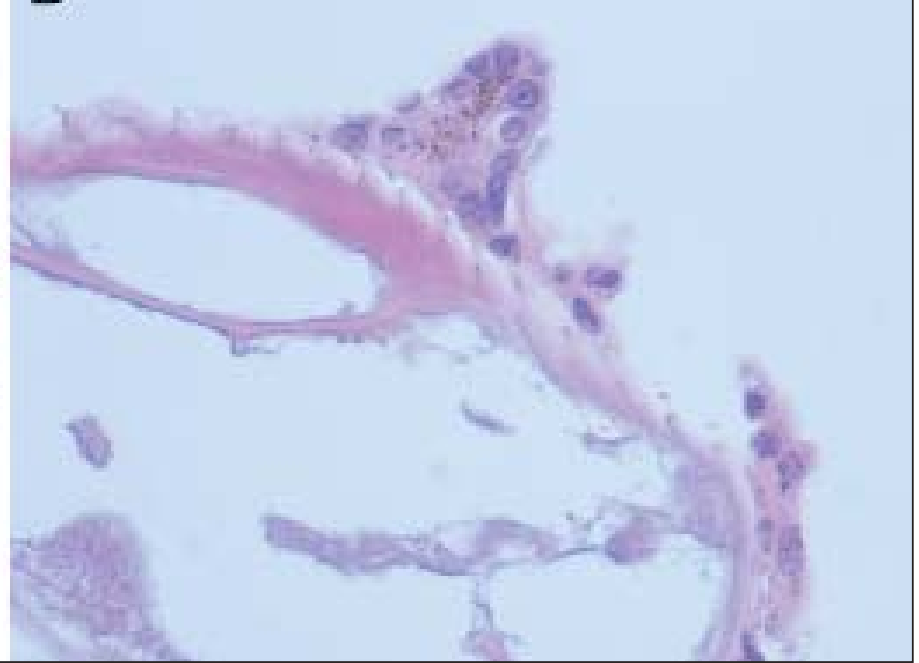

Figure 1 - Anterior internal ophthalmomyiasis. A: Cochliomyia hominivorax larva in the anterior chamber (marked by arrowheads). B: Macroscopic aspect of a fragment of the larva. C-D: Macrophages and foreign body giant cells on the surface (cuticle) of the larva (H\&E, original magnification: $600 x$ ). 
Prompt surgical removal of the offending agent lead to subsiding of the intraocular inflammation and almost complete visual recovery.

\section{RESUMO}

Um caso de oftalmomiíase interna anterior é descrito. Uma mulher de 27 anos proveniente da região Norte do Brasil com uveíte anterior e vitreíte teve uma larva de mosca cirurgicamente removida da câmara anterior do olho esquerdo. A espécie identificada foi Cochliomyia hominivorax. A larva estava coberta por macrófagos e células gigantes de corpo estranho, caracterizando uma reação granulomatosa de corpo estranho.

Descritores: Miíase; Câmara anterior; Infecção por Cochliomyia hominivorax; Dípteros, Relatos de casos [tipo de publicação]

\section{REFERENCES}

1. Ward RA. Myiasis. In: Binford CH, Connor DH, editors. Pathology of tropical and extraordinary diseases: an atlas. Washington: Armed Forces Institute of Pathology; 1976. p.626-30.

2. Cati P. [Anterior internal ophthalmomyiasis with particular regard to clinical manifestations and the pathogenetic problem]. Boll Ocul. 1965;44(3):143-78. Italian.

3. Custis PH, Pakalnis VA, Klintworth GK, Anderson WB Jr, Machemer R Posterior internal ophthalmomyiasis. Identification of a surgically removed Cuterebra larva by scanning electron microscopy. Ophthalmology. 1983;90 (12):1583-90.

4. Gass JD, Lewis RA. Subretinal tracks in ophthalmomyiasis. Arch Ophthalmol. 1976;94(9):1500-5.

5. O’Brien CS, Allen JH. Ophthalmomyiasis interna anterior; report of Hypoderma larva in anterior chamber. Am J Ophthalmol. 1939;22:996-8.

6. Dixon JM, Winkler CH, Nelson JH. Ophthalmomyiasis interna caused by Cuterebra larva. Trans Am Ophthalmol Soc. 1969;67:110-5.

7. Rakusin W. Ocular myiasis interna caused by the sheep nasal bot fly (Oestrus ovis L.). S Afr Med J. 1970;44(40):1155-7.

8. Newman PE, Beaver PC, Kozarsky PE, Waring GO 3rd. Fly larva adherent to corneal endothelium. Am J Ophthalmol. 1986;102(2):211-6. 